\title{
Profesor Andrzej Wiesław Lang (1928-2013). Wspomnienie
}

DOI: http://dx.doi.org/10.12775/SIT.2013.014

Profesora Langa, którego zawsze nazywano w Krakowie Wiesławem, poznałem już wkrótce po rozpoczęciu studiów na Wydziale Prawa i Administracji UJ w roku akademickim 1950/1951. Był już bliski końca studiów (ówcześnie czteroletnich) i naprzód został szybko zastępcą asystenta w Katedrze (zakładzie) Teorii Państwa i Prawa. Nie da się nie przypomnieć, w swoim czasie obszernie pisałem o epoce moich studiów w dobie „klasycznego stalinizmu”, iż właśnie od 1950 r. rozpoczął się na UJ okres dużej aktywności ówczesnych działaczy młodzieżowych (Związek Młodzieży Polskiej). Na moim roku około 90\% ogółu studentów należało do tego związku, nolens czy volens. Byłem wśród tych nielicznych, którzy nie należeli. Wiesław Lang należał do działaczy młodzieżowych, ale w przeciwieństwie do wielu $z$ nich, wyróżniał się zdolnościami intelektualnymi i zainteresowaniami naukowymi. Pamiętam, że żaden $z$ gromkich działaczy młodzieżowych na moim roku studiów, $\mathrm{z}$ wyjątkiem mało wówczas naukowej dyscypliny, jaką była ekonomia polityczna, nie poszedł drogą prawdziwej kariery naukowej. Panująca niewesoła generalnie atmosfera polityczna nie uniemożliwiała jednak naszym profesorom szukania wśród kandydatów na asystentów ludzi zdolnych. Stąd Wiesław wszedł w grono uczniów profesora Jerzego Landego, w swoim czasie zaczynającego karierę naukową jako profesor na USB w Wilnie. Jerzy Lande (1886-1954) był ostatnim wybitnym uczniem legendarnego polskiego filozofa i socjologa prawa, 
Leona Petrażyckiego (1867-1931), twórcy tzw. psychologicznej teorii prawa i moralności. Profesor J. Lande w tych trudnych latach powojennych wychował najlepsze chyba w ówczesnej Polsce grono teoretyków i socjologów prawa: Grzegorza L. Seidlera (przeszedł do UMCS, był jedynym z uczniów J. Landego, który zrobił dość znaczną karierę polityczną w PRL), bliskiego Wiesławowi Jerzego Wróblewskiego (przeszedł na UŁ), a w Krakowie, po odejściu W. Langa do UMK, pozostali w dawnej katedrze J. Landego Kazimierz Opałek (1918-1995), który już w latach pięćdziesiątych należał do bardzo wpływowych partyjnych profesorów na UJ oraz wywodząca się z Wilna, późniejsza profesor Maria Borucka-Arctowa, którą osobiście bardzo wysoko ceniłem. W sumie był to zespół znakomity, w którym W. Lang, najmłodszy z nich, wkrótce zaczął się wyróżniać. Dodać może i warto, że w skromnej ówczesnej siedzibie katedry przy ulicy Ziai 5 (nieopodal Collegium Novum UJ), obok Teorii Prawa mieściła się Katedra Prawa Państwowego, Katedra Historii Doktryn Politycznych.

Wśród luminarzy tego środowiska wymienić należy przynajmniej profesora Konstantego Grzybowskiego (1901-1970), w swoim czasie ucznia i zięcia Stanisława Estreichera, a po wojnie niewątpliwie jednej $z$ najbarwniejszych, ale i najciekawszych postaci na wydziale, oraz późniejszego profesora Marka F. Sobolewskiego (1925-1983), w tych latach bliskiego kolegi W. Langa, który podobnie jak i sam Wiesław, ze swojej wczesnej działalności w PZPR przejdzie na pozycje tzw. rewizjonizmu w łonie PZPR, by po latach reprezentować postawę zdecydowanego opozycjonisty i dysydenta. Takie było najbliższe środowisko Wiesława, z którym szczególnie się zbliżyłem około 1956 r. W dobie „odwilży” październikowej W. Lang należał do otwartych krytyków epoki stalinowskiej i w okresie lat 1956-1964 reprezentował środowisko wydziałowej opozycji w PZPR wobec polityki „odchodzenia” od obietnic Października 1956. Ja, także $z$ uwagi na moje bardzo prześladowane w latach stalinowskich środowisko rodzinne, nigdy nie byłem związany z żadnymi strukturami w ramach systemu, ale obserwowałem (i dyskutowałem) przedstawicieli tej opozycji wewnątrz systemu, o czym, nb. obficie, niektóre osoby donosiły równocześnie i na Wiesława, i na mnie. Wkrótce zreorganizowane kierownictwo PZPR na UJ podjęło 


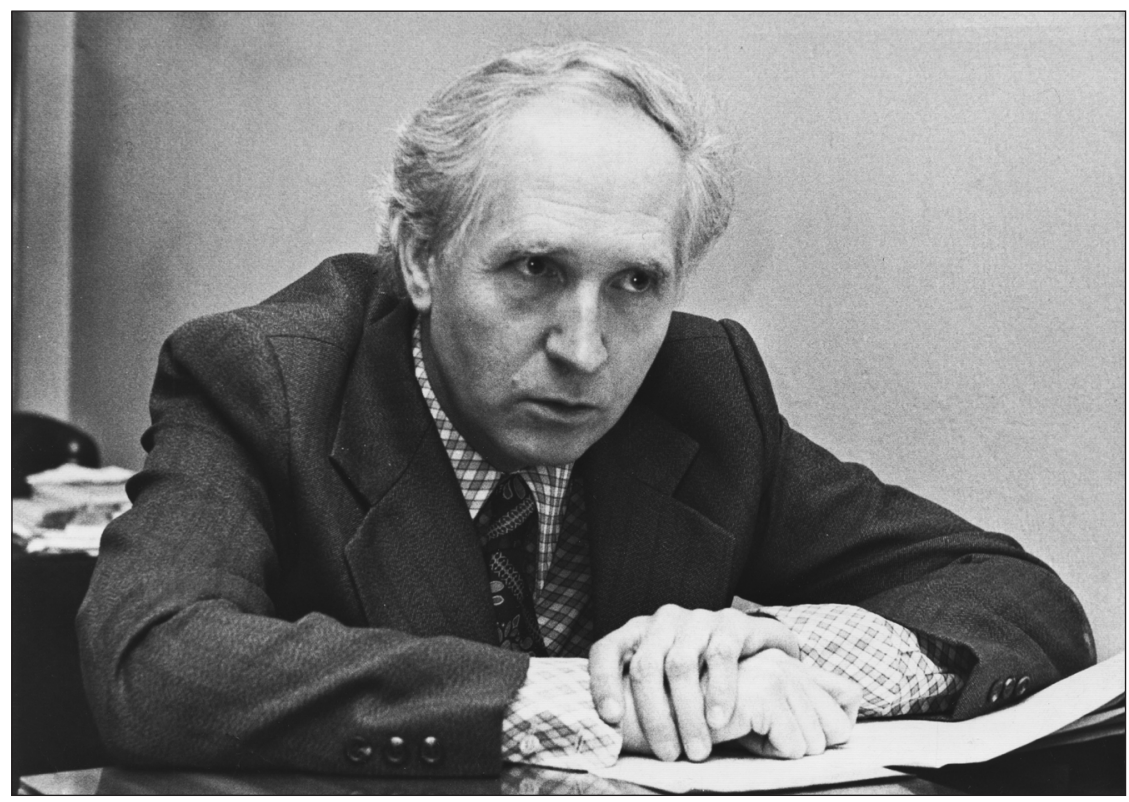

Profesor Andrzej Wiesław Lang (1928-2013)

zdecydowaną walkę z opozycją. Wiesław Lang miał wiele kłopotów, a jego przyjaciel, także bardzo zdolny ówczesny adiunkt, Andrzej Piekara, został z UJ usunięty.

Rozpisałem się w tej kwestii zarówno dla ukazania trudnej epoki, w której przyszło nam działać, jak i dla wskazania, $z$ jakiego środowiska, z jakim dorobkiem niezależnego myślenia, szeroką wiedzą filozoficzną i socjologiczną, W. Lang będzie się przenosił do Torunia. Nie jest moim celem ani nie mam wystarczających kompetencji merytorycznych, by omawiać dorobek ściśle naukowy Wiesława. W 1958 r. zrobił doktorat, chyba w dużej mierze pod wpływem swojego pierwszego mentora J. Landego. O ile pamiętam, to publikacja doktoratu już przechodziła pewne kłopotliwe koleje. Jerzy Lande, przypomnijmy, wpajał swoim uczniom zasadnicze, bardzo fundamentalne metodologiczne podstawy naukowe, ale i błyskotliwą orientację w dorobku L. Petrażyckiego oraz zainteresowania socjologią prawa i moralności. Jerzy Lande, którego zachowałem w mojej pamięci jako wykładowcę najwyższej miary, mimo ciężkiej choroby serca, z którą mierzył się od lat, był do końca swej dzia- 
łalności daleki od ówczesnej oficjalnej, quasi-marksistowskiej teorii państwa i prawa. A o tym, iż u wielu swoich uczniów pozostawił trwały ślad, świadczy także i to, że po zelżeniu po 1956 r. cenzury w PRL udało im się wydanie fundamentalnych prac J. Landego.

Wiesław Lang, mimo wszystko, zdołał obronić w 1964 r. habilitację na UJ (Obowiązywanie prawa, PWN, Warszawa 1962) i uciekając od osób pilnie go śledzących, przeszedł w 1964 r. na odnowiony Wydział Prawa i Administracji UMK, który cierpiał na braki kadrowe. Podobnie bowiem i autor tych słów po habilitacji w 1966 r. zdecydował się, nie bez wahań, przejść na UMK, gdzie ofiarowano mu kierownictwo katedry, a w Krakowie moja sytuacja kadrowa była równie niewesoła jak Wiesława. Trudno jednak nie dodać w tym miejscu, iż na UMK profesor W. Lang ponownie spotkał się $\mathrm{z}$ atakami miejscowej organizacji partyjnej za głoszenie poglądów niezgodnych $z$ oficjalną linią. Moim zdaniem jego pozycja umocniła się na wydziale dopiero po 1970 r., kiedy kilku jego głównych oponentów przeniosło się na nowo utworzony uniwersytet w Gdańsku bądź szukało kariery w Warszawie. Ożywiona przecież działalność naukowa profesora W. Langa nie zmieniała faktu, iż władze dłuższy czas blokowały jego awanse naukowe. Taka była $\mathrm{w}$ tych czasach cena niezależności intelektualnej.

W latach 1980/1981 W. Lang podjął raz jeszcze działania zmierzające do reformy systemu (powstawanie w Toruniu tzw. struktur poziomych PZPR zainicjowane $\mathrm{w}$ gronie bliskim Wiesławowi), co oczywiście w latach stanu wojennego przynosiło ponowne kłopoty. Natomiast późne lata osiemdziesiąte i dziewięćdziesiąte były swego rodzaju apogeum twórczości naukowej W. Langa i to w dużej mierze na forum międzynarodowym, dzięki publikacjom $z$ zakresu filozofii prawa, problemów granicznych między prawem a moralnością, pozycją jednostki i jej prawami.

Moje uwagi mają charakter bardzo osobisty. Chciałbym podkreślić, iż choć nieraz mogliśmy się różnić w poglądach, zawsze zachowywaliśmy przyjacielskie stosunki, także w latach, kiedy moje kłopoty polityczne drastycznie ograniczały krąg moich znajomych.

Wiesław Lang był zawsze człowiekiem dialogu i dyskusji. Znany był $\mathrm{z}$ bardzo przyjacielskiego stosunku do studentów, nie mówiąc 
o współpracownikach. Jego sposób bycia w dzisiejszym, dość prostackim świecie, wydawać się mógł staroświecki. Była w tym nie tylko pewna elegancja, ale i delikatność w traktowaniu otoczenia, która nie wykluczała twardej, ale grzecznej obrony własnego zdania. Był nade wszystko intelektualistą, człowiekiem, który swoje koncepcje teoretyczne czy filozoficzne przeciwstawiał zgrzebnej nieraz rzeczywistości tych czasów. 
